\title{
The Eurasian Economic Union: Realities and Challenges
}

\section{Seilbek Mussatayev}

Ph.D. in Political Science, Associate Professor, Chair of Political Science, Department of Philosophy and Political Science, Al-Farabi Kazakh National University, Almaty, Kazakhstan

\section{Assem Kaidarova}

Ph.D. in Political Science, Associate Professor, Chair of Political Science, Department of Philosophy and Political Science, Al-Farabi Kazakh National University, Almaty, Kazakhstan

\section{Maigul Mekebaeva}

Candidate of Political Science, Associate Professor, Chair of Political Science, Department of Philosophy and Political Science, Al-Farabi Kazakh National University, Almaty, Kazakhstan

\section{Doi:10.5901/mjss.2015.v6n4s3p664}

\begin{abstract}
Realities and current problems of the Eurasian Economic Union. In this article the authors examine the impact of integration processes on the competitiveness of national economies of the participating countries of the Eurasian Economic Union (EAEC). Any integration, including integration within the EAEC affects the economy of participants in two ways: on the one hand favorably promotes multilateral mutually beneficial business contacts, and on the other hand, feels the strength, competing with each other, the individual national economies. The authors comprehensively investigated the current situation and problems of the EAEC with the use of different methods of political analysis (comparative and system analysis, content analysis, event analysis, SWOT-analysis, and others.). In a sufficiently sharp polemical form, based on credible evidence materials, the article shows not only the integration of interaction, but also features of competition within the EAEC, the causes of conflict, as well as the consequences that resulted in the devaluation of the ruble and the dumping prices in Russia, which in turn all have a negative impact on the competitiveness of the economies of Kazakhstan and Belarus.
\end{abstract}

Keywords: integration, union, regional economic integration, national economy, Customs Union.

\section{Introduction}

The Eurasian Economic Union (hereinafter the EEU) is an international organization for regional economic integration, the Member States are: Kazakhstan; Russia; Belarus; and Armenia. According to the Article 1 of the "Treaty on the Eurasian Economic Union" of May 29, 2014 (signed in Astana city, Kazakhstan), the EEU is "an international organization for regional economic integration, shall posses international legal personality, introduce the free movement of goods, capital, services and workforce, a coordinated, coherent and unified policy in the fields of economy defined in this Treaty and international agreements within the Union" [1.]

Brief overview: in 1994, at Lomonosov Moscow State University, the Head of State Nursultan Nazarbayev announced the idea of integration in Eurasia. The initiative of the President of Kazakhstan was implemented in phases: in 2000, Treaty on the establishment of the Eurasian Economic Union (EEUC) was signed; since 2010 the Customs Union (CU) has been operating; and from 2012, Kazakhstan; Russia; and Belarus have moved to the third stage of the integration construction - the Single Economic Space (SES) was established. A year ago, the aforementioned Treaty for the establishment of the EEU was signed, and came into force on 1 January, 2015.

The EEU is gradually expanding, Kyrgyzstan shall be a full member of the Eurasian Union as of May 29, 2015, as well as the Government of Tajikistan has expressed interest to join the EEU and stated that reviews the possible consequences for the country's economy if the decision is made. Prospects and possibilities of the EEU extension are not limited to these countries. As known, on October 24, 2013, at a meeting of the Supreme Eurasian Economic Council in Minsk (Belarus,) the President of Kazakhstan Nursultan Nazarbayev said that Abdullah Gul, President of Turkey had spoken to him with a request to join the Customs Union (the intermediate stage of the EEU.) "Turkish President contacted 
me to ask whether Turkey could be a part of the Customs Union," - said Nazarbayev. "Turkey is a large country, we have a common border. Wherever I go to the West I get asked whether we are creating another Soviet Union or something to be governed by Russia. And I had to explain that we do nothing of the kind. So if we admit Turkey maybe such questions stop," - Nazarbayev proposed to the Presidents of Russia and Belarus. [2]

The allies have responded positively on this proposal. In turn, Russian President Vladimir Putin said that India also took the initiative of signing the agreement on free trade zone with the Customs Union' countries: "Our big friend - the Prime Minister of India has just visited us. He asked me to raise this issue in our meeting today that India would like to consider the possibility to sign an agreement on free trade zone with the Customs Union, - Russian President was quoted by RIA Novosti. - I think that referring to the Indian market size, the prospects for the development of Asia as a whole, we need to take this suggestion seriously"[3.]

If in the future Turkey and India will become the EEU Member States, then this organization will play a key role in world politics and economics. The idea is that the ultimate goal of the EEU is not an expansion, but full integration; modernization; cooperation and competitiveness of national economies; and creation of conditions for sustainable development to improve the living standards of the Member States.

However, the realities of integration within an the EEU are not so rosy. According to the experience of the European Union (EU), the economic gap between new and old members of the EU becomes more and more obvious. Economic development, GDP per capita of many EU member states have not reached even half the average index of the previous organization structure. Germany and France are considered to be the EU flagships, while the share of other members of the Union in the overall economy lags behind, and some countries are still experiencing severe economic crisis. Economic indicators of European countries and some of the "young" EU member states are very different; the proportion is one in four. To bridge this gap is hardly possible, and this imbalance creates additional problems for the EU development. Such countries as Greece generally want to secede from the EU, blaming their troubles stringent requirements of the European Parliament and the European Commission's budget savings. Endless financial and economic crisis, which shakes the Eurozone for a decade, has become the number one problem in the entire EU as a whole, not only for individual Member States. Shortsighted policy of the European Commission of last convocation, which focused only on solving financial problems resulted in an aggravation of social problems that come from the local level to the supranational one and has taken threatening features. In such circumstances, the accession of new member countries into the European Union can easily result in conflicts related to the funds reallocation. On the one hand, developed countries have resisted additional contributions to General funds. On the other hand, countries that assisted (Spain; Ireland; and Portugal), want to continue to receive these funds.

Similar economic problems and imbalances are observed within the EEU. To understand the current situation there is a need for comparative political analysis of geographic; economic; and socio-political indicators of the EEU member countries.

The EEU member states, as in the EU also vary significantly from each other in terms of economy; territory and population; natural resources; the level of scientific, technological and industrial base; infrastructure; and etc. For example, the area of Russia is $17,125,407$ square kilometers, ranking first worldwide, with the population of $146,267,288$ people, the 9th place in the world. The GDP nominal level - 2, 097 trillion USD, GDP per capita - 14,591 USD [4.] On the territory of the Russian Federation there are enormous reserves of raw materials and energy resources. In particular, there are large deposits of oil; gas; coal; potash salts; nickel; tin; aluminum raw materials; tungsten; gold; platinum; asbestos; graphite; mica; and other minerals. Russia discovered more than 20,000 mineral deposits, all kinds of natural resources, almost the whole periodic table. According to the results of the 2011 geological surveys, the hydrocarbon reserves in Russia have increased. According to preliminary data, oil reserves increased by 600 million tons, and gas at 900 billion cubic meters. Under the annual "Statistical Review of World Energy" by the BP (British Petroleum) oil company, by the end of 2013 Russia ranked first in the world in natural gas reserves (44.8 trillion cubic meters), and in oil was on the 8th place - 93030000000 barrels, being overtaken by a number of the Gulf countries and Venezuela. At the same time Russia is the leader in oil production, is second in gas production, after only the United States [5]. That is, the Russia's main exports are the oil and the gas. Among the EEU members the Russian Federation is notable for powerful industrial potential, with thousands of factories of mechanical engineering; instrumentation; light industry; chemical; and food industries. It has access to the seas. Navy and Military-industrial complex of Russia are among the strongest worldwide.

The following EEU member - the Republic of Kazakhstan. Territory - 2724902 km²; ranks the 9th place in the world, but yet the population number is small -17439271 , it is the 63 rd place in the world. Population density is 6,4 persons per 1 square kilometer (the 184th place in the world.) The GDP is 224,415 billion US dollars, 12456 per capita. Kazakhstan, as well as Russia, is also rich with minerals. According to the "Statistical review of world power" (Statistical 
Review of World Energy) prepared by the BP, Kazakhstan takes the 12th place in the world on volumes of proved recoverable oil reserves and the 20th place on gas reserves. More than 80 fields are under development. For years of independence oil production increased in Kazakhstan more than 3 times, having reached 80 million tons, and on gas more than 5 times - to 40 billion cubic meters [6.] The BP estimated naphtha reserves in Kazakhstan as 30 billion barrels, or 3,9 billion tons that makes $1,8 \%$ of world reserves, and gas reserves of 1,3 trillion CBM ( $0,7 \%$ of world reserves.) The analysis of Kazakhstan's industry structure testifies to a dominance of raw sector. In total volume of industrial production in manufacturing industry accounted for slightly more than 30\%, mining - more than $60 \%$. On the initiative of the RoK President the State program on forced industrial-innovative development of the country is under implementation but the targeted results are not yet available. Kazakhstani industry lags behind both from the Russian and the Belorussian ones. Because of this, the export potential of Kazakhstan focuses on raw materials and is formed by fuel, metallurgical and chemical industries. In structure of the Kazakhstan export the main share is occupied by naphtha and oil products (35\%); other important commodity groups are non-ferrous metals (17\%); ferrous metals (16\%); ores (12\%); the specific part of export is the share of grain crops (9\%.) Statistical data specify that the main exported goods of the country is the commodity group "Fuel and Energy Goods", and "Metals and their products" in export of Kazakhstan take the 2nd place [7.] In this regard the Kazakhstan's and the Russia's export are very similar, even it would be possible to call them "raw competitors" though are the EEU allies. Due to this fact, the negative balance between export and import is observed in Kazakhstan. For 2014, total exports of Kazakhstan made 78237,8 billion USD, import - 41212,8 billion USD, the negative balance - 37025 billion USD. In 2014, according to the Statistics Committee under the RoK Ministry of National Economy, the ratio of Kazakhstan's export-import within the EEU was shown by following results: export to Russia 5178,1 million USD, import from Russia - 13730,3 million USD. The negative balance - 8552,2 million USD. Export of Kazakhstan to Belarus - 29,2 million USD, and import from Belarus - 727,6 million USD. The negative balance makes 698,4 million USD. [8.]

The following EEU member is Belarus. Its territory is $207600 \mathrm{~km}^{2}$; ranks the 84th place in the world with 9466000 residents; GDP - 166,786 billion US dollars, with 17620 per capita. Belarus is famous for water resources; woods; rich flora and fauna. However, natural minerals are limited, in the Gomel region several dozen small oil fields are known, which annually produce just over 1.5 million tons of oil and a minor amount of natural gas. In the Pripyat valley deposits of brown coal and oil shale are known. Throughout of the Republic's territory there are rich peat deposits - about 7 thousand peatlands. There are two large but deep deposits of iron ore and a few small deposits (occurrences) of native copper; copper pyrites of rare earth metals; beryllium and uranium ores. A number of deposits of raw materials for production of building materials and sources of fresh water and mineral water are under development [9.] Belarus has developed energy; engineering; agriculture; chemicals and forestry; construction; construction materials; and mining. Major exports are oil products; potash fertilizers; machinery; chemical and food industries. However, despite this, after the accession to the Customs Union foreign trade balance of Belarus became negative, for example, by the end of 2013, the excess of imports over exports amounted to 5,820 billion USD, and in 2014 - 4396 billion USD [10.] Besides, the main share of import was made by the Russian goods.

As for Armenia, the place and the role of this member state as the EEU part is still insignificant: the territory - 29 $743 \mathrm{~km}^{2}$ (the 138th in the world); the population - 3 017,1 thousand people (135th); GDP of 9,951 bln. dollars USD, with $\$ 3351,63$ per capita [11.] And the most important - Armenia has no common borders with other EEU member states. At this stage, membership of Armenia in EEU has geopolitical value, rather than economic one. Armenia is also largely joined the EEU for the preferential energy supply and, moreover, has become a sort of "substitute of Ukraine" as the place of the fourth member of the organization was originally meant for that country. But the future role and importance of Armenia in the EEU integration processes may increase: first, it is located in the geostrategic region; secondly, a subsoil of Armenia is quite rich with ore minerals; thirdly, Armenia has rich natural and recreational resources; historical places; has huge potential for development of international tourism; fourthly, water resources of Armenia blows the mind of the person: on the territory of this highland there are about 9480 small and larger rivers; over 100 lakes; fifthly, Armenians can brag with rich flora and fauna of the homeland.

Armenia is the industrial and agrarian country with considerable reserves of copper and molybdenic and complex ores; bauxites; structural stone; mineral waters; fields of precious metals; and semiprecious and ornamental stones. Production of synthetic rubber; the textile; food industry; production of structural materials and mechanical engineering are developed. The structure of GDP, by estimates of CIA of the USA, in 2010 had the following appearance: services sector - 31,4\%; industry - 46,6\%; and agriculture - 22\% [12.]

2013: Armenia's foreign trade turnover increased by 5.6\% compared to 2012 and amounted to $5,956,800,000$ USD. At the same time, exports amounted to $1,480.0$ USD, having increased by $7,2 \%$, imports - 4476800000 USD, increased by $5.1 \%$. Its negative balance is $2,996,800,000$ USD. The export leader to the Republic of Armenia is Russia 
(22.6\%), followed by Bulgaria (10.3\%), third - Belgium (8.9\%.) By the end of 2013 the main importers of Armenia: Russia (24.8\%); China (8.6\%); and Germany (6.3\%.)

2013: The analysis of commodity structure of Armenia's export shows that the main export was submitted by the following commodity groups: production of agriculture and prepared food - 415,4 million USD (increase by $28,8 \%$ compared to 2012); mineral products - 407,2 million USD (growth by 1,2\%); non-noble metals and products from them 308,8 million USD (recession for 10,0\%); precious and semiprecious stones, precious metals and products from them 188,0 million USD (growth by 8,6\%); textiles, tanning products and footwear - 45,4 million USD (increase by 80,0\%) [13.]

Summing up the above comparative analysis it is possible to draw such conclusions:

- First of all, the most powerful and the biggest economy within the EEU is theRussian one (3/4 GDP of the Eurasian Union.) Respectively, the economic dominance of Russia in the Union is quite logical. From the very beginning of the Eurasian integration processes, in almost all areas of cooperation Russian interests have dominated. However, the Union members raised fears, as if the Russian economic hegemony would not develop into a political one. The most important thing for the EEU member states would be to prevent Russia's political domination. There are reasons for concern. Russia wanted to amend the EEU Treaty with different political provisions on common citizenship; general qualification system in education and professional competencies; creation a single parliament; introduction of a common currency; and etc. However, Kazakhstan has actively resisted Russian attempts to give political dimension to the economic union, and Belarus has greatly supported these efforts of Kazakhstan. Many analysts are unanimous that excessive desire of Russia to political dominance in the post-Soviet space is a major cause of the Ukrainian crisis, and in this regard, see the EEU' future as a union of four Republics in the field of energy trade only.

- Secondly, due to economic superiority of Russia other EEU members began to experience some difficulties with regard to ensuring the national interests, especially threatening the economic security. For example, a sharp increase in Russian imports has created a big problem for the Kazakhstani business. Today's reality is that on our shelves there are many Russian products, especially in the northern regions. Moreover, the Russian companies started to dominate in the sphere of logistics; equipment supply; automobile market; food market; and so on. Kazakhstani producers are noncompetitive. Taxes; working places; opportunity for Kazakhstan's small and medium business to work and develop successfully would be the acute issues. In theory, Kazakhstan would benefit from integration, it was much told about it at the most different levels. But in practice everything turned out on the contrary. The EEU was like one-way road: toward Kazakhstan it is allowed to import any Russian products, whereas products «Made in Kazakhstan» on the RF territory met huge impediments including different licensing procedures in the form of sanitary and epidemiological standards; technical regulations; licensing; and etc.) On this issue, even the President of Kazakhstan had to make severe reproof;

- Thirdly, in the mutual trade between the EEU member states there is the imbalance, tendency of trade deficit (the negative balance (the sign "minus" is put) - import exceeds export.) For example, in Kazakhstan after establishing the Customs Union import from Russia grew three times, besides, that export to Russia from Kazakhstan remained at the previous level. The situation with Belarus is even more indicative. For example, in quantitative terms, the import of Belorussian goods in Kazakhstan is not so significant, but it is seven times higher than Kazakhstan's exports to Belarus. Similar situation is in export-import between Belarus and Russia. The share of Armenia in the mutual trade between the EEU countries is still poor though here import (especially Russian) prevails over export as well. The ruble devaluation resulted in tremendous benefits for the Russian producers. On the one hand this enhanced the "Made in Russia" brand appeal, on the other hand forces the Russian partners to introduce protective measures.

- Fourthly, in the structure of export of the EEU natural raw materials prevail: naphtha; gas; coal; iron oxides; and other minerals. The fuel and raw specialization of a number of economies of the EEU countries, boosts rivalry between partners. For example such conflict of interests is observed between Russia and Kazakhstan. On April 28, 2014, at lecture at Lomonosov Moscow State University, the President Nazarbayev emphasized that the Eurasian Union "is possible only on the principles of voluntariness; equal rights; the mutual benefit; and consideration of pragmatical interests of each member country" [14.] However, in practice, to respect these principles were difficult.

- Fifth, there are still different institutional differences between the EEU countries, which adversely affect the integration deepening. For example, businessmen complain of different approaches of standardization; certification; and goods registration. Due to interdepartmental non-coordination there are bureaucratic barriers; idle times; and corruption manifestations. Subsequently on border check points and customs terminals the 
kilometer queues are often formed. That is an incompleteness of formation of the EEU identity as it is available in the EU.

In the formulated conclusions only the most acute issues of the EEU have been specified while there are a lot of challenges and integration issues. We are positive that over time, in process of the EEU development and deepening of mutually beneficial cooperation these contradictions will be solved considering the national interests of all EEU members. The EEU has a huge opportunity and potential to implement this. In order to determine the prospects of the regional economic organization it is necessary to apply the SWOT-analysis method. The SWOT-analysis is a research method to identify internal and external environment factors of the organization and its division into four categories: Strengths, Weaknesses, Opportunities and Threats.

So, the EEU Strengths: 1) The new Union covers the largest geographical area with access to all four corners of the earth; 2) A single consumer market (over 170 million consumers); 3) The vast natural resources (in the territory of the union a significant part of the world's supply of minerals is concentrated); 4) The EEU members inherited from the Soviet Union to great extend: infrastructure; industrial mega-cities and qualified personnel; agricultural farms; military-industrial complex; qualified human capital;and etc. We can only recover partially broken economic, commercial and humanitarian relations; 5) The Union is located on the very important geostrategic region between the East and the West, in the middle of the EU, China; India; Central Asia; and the Middle East.

The EEU Weaknesses are - first, the lack of Union identity. In the post-Soviet countries the stereotypes and fears of a totalitarian Federal past have yet remained. Since independence, each country fought for itself, protecting its own national interests. Therefore, within the Eurasian Economic Union, each member state hogs the cover to itself; at this stage of the development, the integration union reminds the Ivan Krylov's fable of a swan, a crawfish and a pike. Overcoming of dissociation and formation of new allied consciousness will require certain time. Secondly, the EEU lags behind the developed competitors in the areas of development of science; innovation; technique; and technology. In the EEU economy the raw orientation prevails, the actual sector of economy is poorly developed, the knowledge-intensive production; small and medium business; and tourism are in embryo. Thirdly, in the EEU countries there are high indexes of corruption; bureaucracy; and clannishness. Fourthly, interstate structures are not completely coordinated and the national legislations of the EEU members are not harmonized which in turn promote integration braking. Fifthly, there is the strong dependence of the EEU economy from external factors such as economic sanctions of the western countries on the relation of Russia; the world prices for energy carriers and natural resources; the US dollar and EURO exchange rates; and etc.)

Regarding the EEU Opportunities, it is possible to claim safely that possibilities of the Union are simply great if to use them rationally. The EEU cannot only provide completely the requirements, but also to become the world supplier of raw materials, goods and services. In addition, the EEU will be perhaps expanded with the introduction of new member allies. The EEU transit opportunities are very high too, with the start of a transit transport corridor "Western EuropeWestern China" will revive the Great Silk Way in a new format. In addition, the EEU has actual opportunities to become the world financial center, a developed economic zone with the favorable investment climate. The EEU opportunities can make a long list.

And, of course, there are the EEU Threats. But the most important from them:

- threats of terrorism, extremism and separatism. These threats are inherent in each member state of the integration union;

- particular threat of economic character proceeds from excessive dollarization of national economy of certain EEU members. The people live in fear for devaluation;

- as the basis of the EEU economy is made by sale of hydrocarbons and iron oxide on the world market, within the Union the strong dependence from the price on raw material and energy resources is felt;

- larger social and economic problems can arise due to different economic development of allies. For example, the Russian economy is considered the most industrially developed compared to other EEU countries. Therefore, the Russian goods have low prime cost; can be on sale at the dumping prices. Unequal competition creates problems for producers of the allied countries. This might result in threats of workplaces downsize; unemployment increase; social tension; and etc.

\section{Conclusion}

As shown by a comprehensive analysis, it is extremely difficult to give an unambiguous assessment of EEU at this stage since integration of Eurasian Union only began to function. Nevertheless, the first steps of the EEU demonstrated strengths and weaknesses of the integration processes. We can only learn from the shortcomings of interaction and 
resolve emerging problems of cooperation jointly.

\section{References}

Dogovor o Euraziskom economisheskom souse ot 29 maya 2014 goda https://docs.eaeunion.org/sites/storage0/Lists/Documents la089f4c6-02da-4461-b033-3f5d122e0020/e57db9f2-9589-4b26-be1e-b1a43862c6ed_635375701449140007.pdf

Mager Y. Nobye gorizonty // Kazakstanskaya Pravda. 25 Oktybrya 2013 goda. - S. 2

Duvanov A. Tamozhennui soyz: plus -Tursya, minus - Ukraina, India -v ume? //RIA novosti http://ria.ru/analytics/20131025 1972555134.html\#ixzz3VkQdCc9Z

World Economic Outlook Database, April 2014 // http://www.imf.org/external/pubs/ft/weo/2014/01/weodata/weorept.

Obzor ustoishivogo razvitiya v 2013 gody // http://www.bp.com/ru_ru/russia/press/publications.htmlg

Shurenov N. Osenka pozisi Respubliki Kazakhstan na mirovom rynke nefti // http://group-global.org/ru/publication/14234-ocenka-poziciyrespubliki-kazahstan-na-mirovom-rynke-nefti

Pokazateli vneshney torgovli i struktury importa I eksporta RK // http://kazdata.kz/04/2014-01-export-import-kazakhstan.html

Vneshya I vzaimnaya torgovlya. Osnovnye pokazateli za 2012-2014 gody /I http://stat.gov.kz/faces/wcnav_externalld /homeNumbersCrossTrade;jsessionid

=8yZ5VYKLffB71J3RK5LKfCX9L3sGhzrlM5nJGbSVgysN1x68JJJB!1778126280?lang=ru\&_afrLoop=268669934569704\#\%40\% 3F afrLoop\%3D268669934569704\%26lang\%3Dru\%26 adf.ctrl-state\%3Dbthgi48nc 4

Karabanov A.K. Problemy osvoenya mineralno-syrevux resursov Belarusi// Geographical sciences in realization of sustainable development strategy in globalizing world (to the 100th anniversary of Professor N.T. Romanovskij): Materialy Mezhdunar. naush.-prakt.konf., 25-28 окт. 2012 g. - Minsk: izd. Sentr BGU, 2012. -362 s.

Osnovnye pokazateli vneshya torgovlya (dannye Nasionalnogo statistisheskogo komiteta Respubliki Belarus) II http://belstat.gov.by/ofitsialnaya-statistika/otrasli-statistiki/torgovlya/vneshnyaya-torgovlya_2/osnovnye-pokazateli-za-period-s-pogody_10/osnovnye-pokazateli-vneshnei-torgovli/

Statistikisheskie pokazateli. Nasionalnaya statistikisheskaya sluzhba Respubliki Armenya// http://www.armstat.am/ru/?nid=126

The World Factbook // https://www.cia.gov/library/publications/the-world-factbook/geos/am.html\#Econ

Armanya. Vneshyeekonomisheskaya deyatelnost // http://www.ved.gov.ru/exportcountries/am/about_am/ved_am/

«Ot idei Evraziskogo soyza - k nobym-perspektivam evraziskoi inegrasii» // http://akorda.kz/ru/page/page_216601_vystuplenieprezidenta-respubliki-kazakhstan-n-a-nazarbaeva-v-moskovskom-gosudarstvennom-universit?print 